\title{
The effect of non performing financing volume with inflation as moderating variables on sharia commercial banks
}

\author{
Mirasanti Wahyuni, ${ }^{1}$ Fika Azmi ${ }^{2}$ \\ 1,2STIE Bank BPD Jateng, Semarang, Indonesia \\ email: mirasanti.wahyuni@gmail.com
}

\begin{abstract}
Purpose - This study was conducted to examine the effect of the amount of financing on Non Performing Financing (NPF) and inflation as a moderating variable in sharia commercial banks in Indonesia.

Method - This study will be analyzed using the interaction test model, Moderated Regression Analysis (MRA). The population in this study are all Sharia Commercial Banks in Indonesia with sample selection using a purposive sampling method with the requirements of Sharia Commercial Banks (BUS) that have complete data from 2011-2016.

Result - The result is all Islamic banking financing has an influence on NPF with inflation as a moderating variable.

Implication - This is thought to be influenced by internal bank factors in the form of financing volume and bank external factors in the form of inflation. Then what about the conditions of other Sharia Commercial Banks.

Originality - Funding in this study will be divided into financing for profit sharing principles (mudharabah and musyarakah), murabahah, salam, and istishna. The inflation indicator used is CPI.
\end{abstract}

Keywords: volume of financing, profit sharing financing, non performing financing, inflation 
Mirasanti Wahyuni, Fika Azmi

\section{Introduction}

The first Islamic banking was in 1991. Bank Muamalat is the first Islamic bank in Indonesia. Bank Muamalat has a captive market compared to other JIAFR | 80 sharia commercial banks should be able to set an example for other sharia commercial banks. However, Bank Muamalat's capital adequacy ratio per September 2017 was recorded at $11.58 \%$, down from the same period in 2016 of $12.75 \%$. Based on Islamic banking statistics (SPS) as of September 2017 the average national Islamic bank capital adequacy ratio is $16.16 \%$. According to the Chairman of the Board of Commissioners of the Financial Services Authority (OJK), Wimboh Santoso, based on the news detik finance on Thursday, February 15, 2018, customers did not need to worry because Bank Muamalat's liquidity was still good.

The volume of Islamic Bank capital is influenced by internal factors and bank external factors. Possible internal factors that cause disruption of the volume of Islamic Bank capital are the ratio of Non Performing Financing (NPF). Based on financial reports, the NPF or the troubled financing ratio of Bank Muamalat 2015 in gross had crossed the safe limit, namely, 7.46\% or 1.36 trillion, in 2016 it improved in the position of $3.97 \%$ or Rp. 696.2 billion. The September 2017 period again deteriorated with NPF recorded at $4.54 \%$. According to Mutamimah and Chasanah (2002), the amount of funding allocation has an effect on NPF. The results of research conducted by Legowati and Prasetyo (2016), the results obtained that the volume of financing has an influence on NPF.

Financing in Islamic banking is divided into financing based on profit sharing and buying and selling principles. Financing with profit sharing principles, namely mudharabah and musyarakah financing. While financing with the principle of buying and selling, namely murabahah, salam and istishna. The relationship between the customer and bank management has an agency relationship. The owner of the fund (principal) authorizes management as an agency relationship, but then different interests occur. in Islamic financial institutions in the scheme of distributing profit-based 
The effect of non performing financing volume with inflation ...

financing products in Islamic banking, when there is one mudharib as an active party and has knowledge of investment projects that are risky but profitable but do not have the initial funds to finance the project while Shahibul mal as the owner of the fund, and there are differences in interests between the two parties, for example, customers as fund managers ignore JIAFR | 81 contractual relationships and do not act on the interests of Shahibul mal by reporting profits not in accordance with the actual situation. Or even not paying off its obligations to Islamic banks.

There are other factors that also influence the number of NPF in addition to the volume of financing. When viewed from factors outside the bank's internal, it seems that the NPF is also influenced by inflation that has occurred since the last three years. Inflation is an increase in several commodities which are basic needs during a certain period. The inflation rate for December 2017 is higher compared to December 2016 which reached 0.42 percent. However, this is still better than in December two years before, which was 0.96 percent. The annual inflation in December 2017 was also higher than last year's 3.02 percent. According to the Head of BPS on Indonesian CNN (2018), inflation throughout the year was influenced by administered prices, mainly electricity tariff adjustments. Meanwhile, throughout 2017, electricity rates contributed 0.81 percent. The biggest inflation this year was also contributed by the cost of renewing vehicle registration certificates of 0.24 percent and food ingredients such as fresh fish by 0.2 percent and rice by 0.16 percent.

The amount of inflation that occurs affects the ability of customers to pay their debts to banks. If inflation occurs high enough, it will cause a number of prices of basic commodities to rise. This causes a decrease in the ability of customers to repay debts. The customer will choose to fulfill his basic needs, after that he pays the debt to the bank. According to Mutamimah and Chasanah (2002), the volume of financing and inflation can influence the size of the NPF. According to the research of Barus and Erick (2016), Amin, et al (2017) and Saekhu (2015), inflation has an effect on NPF. 


\section{Literature Review}

\section{The Principle of Islamic Bank Financing}

JIAFR $\mid 82$

The principle of financing in Islamic banks is buying and selling, investing and leasing. Definition of financing in Law No. 10 of 1998, financing based on sharia principles is money or similar bills based on agreements or agreements between banks and customers that require customers who accept to return the money or bills within a certain period of time with compensation or profit sharing.

The principle of buying and selling In this principle there are 3 types of business: 1) Murabahah schemes: In this principle, the acquisition price and agreed profit are clearly stated by the seller and the buyer. 2) Salam scheme: In this principle, repayment is made in advance by the buyer before the ordered item is received. 3) Istishna schemes: In this principle based on the agreement of the buyer and seller who is also the producer to provide goods or a product according to the specifications required by the buyer and sold at the agreed price from the beginning.

The principle of investment in financing by Islamic banks consists of: 1) Mudharabah In the Mudharabah principle, acting as shahibul maal is a bank and mudarib is the customer who receives financing. All capital is borne by the bank. Mudharabah consists of mudharabah mutlaqah, which is a bank earning income from the profit sharing ratio which is the bank's right. Then mudharabah muqayyadah where the bank acts as an agent that connects customers who have set certain limits in investment activities to customers who receive investments from this type of mudharabah, and the bank receives a certain fee according to the agreement. 2) Investment with the Musyarakah Scheme In this type of investment, banks and customers combine their capital in a particular business with profit sharing based on an agreed ratio. But when a loss occurs, it is borne by all capital owners based on the proportion of their respective capital. In this scheme the relationship that occurs with financing customers is in the form of partnerships with fellow capital owners. 
The effect of non performing financing volume with inflation ...

\section{Inflation}

Inflation is the tendency of prices to increase in general and continuously. The increase in just a few commodities is not called inflation, except if the increase extends and results in a large increase in the price of other goods. If the increase in prices is seasonal or occasional or does not have further influence it is not inflation.

The inflation indicator is a measure used to calculate the inflation value to determine the inflation rate at a certain time. Inflation indicators are generally calculated using the index number of prices of goods and services. In general there are three inflation indicators, namely CPI, IHPB and GDP deflator. In this study the indicators used are CPI. CPI is generally used to measure price changes (pricechanges), cost of living (cost of living), purchasing power (purchasing power) and inflation rate (general measure of inflation). CPI is used as an indicator to measure price developments in general in Indonesia.

\section{Non Performing Financing}

Asset quality assessment which is one form of risk management to absorb potential losses to BUS and UUS. Analysis of assessment factors regarding business prospects, debtor's performance, ability to pay by considering unspecified components, credit quality is determined to be: 1) Current (Pass), 2) In special attention (special mention), 3) Substandard, 4) Doubtful, 5) Loss.

Non-performing earning assets (NPLs) are earning assets with substandard, doubtful and loss assets. This damages credit risk which is all risks related to the possibility of client failure in paying their obligations or risks where the debtor cannot pay off his debt. Credit risk can occur due to several reasons: 1) The possibility of a loan given by a bank or bonds (debt securities) purchased by a bank does not pay off, 2) Failure to comply with the obligations of the bank involved through other parties, such as failure to fulfill obligations on derivative contracts, 3) Settlement with exchange rates, interest rates and derivative products. 
In a sharia commercial bank, NPL is called NPF or Non Performing Financing which is generally interpreted as problematic credit, which is included in this category, which is classified as substandard, doubtful, or nonperforming. It can be said that NPF is a non-refundable level of financing compared to all financing channeled by Islamic banks or also called problem financing.

\section{Agency Theory}

Jensen and Meckling (1976) define agency theory as a theory of relations between principals and agents, where the principal has delegated authority to the agent in managing the business and making related decisions. Agency Theory is known as a contractual financial relationship involving the owner of the fund with the fund manager. In its application the fund owner (principal) authorizes the management as an agent (agency relationship), but then there is a difference of interests. These different interests can cause information asymmetry from agents to the principal.

Agency theory can occur in Islamic financial institutions in the scheme of distributing profit-based financing products in Islamic banking. Where when there is one mudarib as an active party and has knowledge of investment projects that are risky but profitable but do not have the initial funds to finance the project and Shahibul maal as the owner of the funds, but there are differences in interests between the two parties. For example, customers as fund managers ignore contractual relationships and do not act on the interests of Shahibul Maal by reporting profits not in accordance with the actual conditions.

Factors that cause information asymmetry themselves can be categorized into external factors and internal factors. External factors can be derived from mudharib conditions, namely in the form of the level of honesty, transparency and security of mudarib to restore financing capital. Factors from internal sharia financial institutions that can be in the form of a lack of understanding of the mechanism of work of financing products. Officials authorized to 
The effect of non performing financing volume with inflation ...

approve financing proposals only pursue the target volume of financing channeled without considering the factor of the refund rate.

\section{Hypothesis Development}

According to the agency theory, the principal has delegated the authority JIAFR | 85 to manage the business to the agent but then conflicts of interest occur. In the case of channeling funds from Islamic banks to customers, the agent is a customer of Islamic banks and the principal is the management of Islamic banks. The management demands that the recipient of the funds be always on time to settle the installments and the profit sharing. But the customer also has an interest in raising his business and/or earning more profit from the business that has been carried out. This might trigger customers' dishonesty in paying off their debts to Islamic banks, giving rise to high NPF Islamic banks. The greater the amount of financing channeled to troubled customers it will affect the high NPF. This is in line with the research of Mutamimah and Chasanah (2002), the amount of funding allocation has an effect on NPF. Likewise the results of research conducted by Legowati and Prasetyo (2016), the results obtained that the volume of financing has an influence on NPF.

Apart from the bank's internal factors in the form of the large amount of financing channeled, external factors that also influence it are the existence of inflation. According to the research of Barus and Erick (2016), Amin, et al (2017) and Saekhu (2015), inflation has an effect on NPF. Indonesia's economic conditions in the past 2 (two) years have experienced high inflation. This certainly affects the condition of business finance carried out by sharia bank customers and indirectly affects the ability of customers to fulfill their obligations to Islamic banks.

There are several financing schemes at Islamic commercial banks. The main scheme in Islamic banks is the profit sharing scheme (mudharabah and musyarakah), buying and selling murabahah, salam, and istishna. Each has its own characteristics. In profit-sharing financing, as previously explained, there is a conflict of interest between each fund owner and business manager. Customers and banks want high profits. When inflation occurs, the gap 
between customers and banks is increasingly visible. The bank wants to return large profit-sharing profits and smooth repayment of receivables. While customers experience a dilemma due to rising prices that cause high costs and declining income. Decreasing customer income will affect repayment of debt and profit sharing. Customers tend to report income that is not in accordance with the actual conditions for capital adequacy. If more funding is given to customers and many customers have difficulty paying debt and profit sharing, the NPF value of the bank will increase. Then the first hypothesis:

\section{$H_{1} \quad$ : Profit sharing has an effect on NPF with inflation as a moderating variable}

In the murabahah sale and purchase scheme, the customer pays a certain margin agreed at the beginning. The debt margin and principal must be paid according to the agreement. The more murabahah financing given to customers and high inflation, the possibility that customers will choose to fulfill basic needs first and then pay off debts and margins. If this happens to most customers, the NPF of Islamic banks will be affected. Then the second hypothesis:

\section{$\mathrm{H}_{2} \quad$ : Murabahah financing has an effect on NPF with inflation as a moderating variable}

A special characteristic in greeting contracts is repayment after the price agreement at the time of the agreement. When high inflation is likely to affect the ability of customers to pay the agreement price. Because the possibility of the price offered by the bank is too high, but the customer really needs the financing for his business. So that this has an effect on the smooth repayment of greetings transactions. Then the third hypothesis:

\section{$\mathrm{H}_{3} \quad$ : Salam financing has an effect on NPF with inflation as a moderating variable}

Special characteristics of the Istishna contract are usually used to finance physical development projects or infrastructure. The high inflation causes an increase in a number of costs. This causes a decrease in the customer's 
business income, thus reducing the ability of customers to pay debts. On the other hand, the customer must pay off his Istishna debt according to a specified time. If this happens to most customers, the NPF of Islamic banks will increase. The fourth hypothesis is

$$
\begin{aligned}
& \mathrm{H}_{4} \quad \text { : Istishna financing has an effect on NPF with inflation as a } \\
& \text { moderating variable }
\end{aligned}
$$

\section{Research Methods}

The population in this study is Sharia Commercial Banks in Indonesia. Samples were taken using purposive sampling method. The criteria used are Sharia Commercial Banks that have published financial reports by presenting complete required data from 2011 to 2016 . The data to be collected is secondary data on profit-based financing volume, murabahah financing volume, salam financing volume, istishna financing volume, inflation and NPF.

\section{Revenue Sharing}

Profit sharing financing used is financing with mudharabah contract and Musyarakah contract. The volume of financing based on the results under study, obtained from the balance in the quarterly period of profit sharing financing produced by sharia commercial banks which are the object of research.

\section{Financing Murabahah}

Murabahah financing is margin based financing. The volume of murabahah financing studied, obtained from the balance in the quarterly period of murabahah financing produced by sharia commercial banks which are the object of research

\section{Salam Financing}

Salam financing is financing with a margin contract with early repayment. The greeting financing volume studied, obtained from the balance in the 
quarterly period of greeting financing produced by sharia commercial banks which became the object of research

\section{Istishna Financing}

JIAFR $\mid 88$

Istishna financing is margin-based financing whose repayments can be paid in installments. The Istishna financing volume studied was obtained from the balance in the quarterly Istishna financing period produced by sharia commercial banks that became the object of research

\section{Inflation}

The inflation indicator is a measure used to calculate the inflation value to determine the inflation rate at a certain time. Inflation indicators are generally calculated using an index number of prices of goods and services. In general there are three inflation indicators, namely CPI, IHPB and GDP deflator. In this study the indicators used are CPI. CPI is generally used to measure price changes (pricechanges), cost of living (cost of living), purchasing power (purchasing power) and inflation rate (general measure of inflation). CPI is used as an indicator to measure price developments in general in Indonesia.

\section{Non Performing Financing}

Non-Performing Financing which is generally interpreted as problematic credit, which is included in this category, which is classified as substandard, doubtful, or non-performing. It can be said that NPF is a non-refundable level of financing compared to all financing channeled by Islamic banks or also called problem financing.

The size of financing includes substandard financing, doubtful financing and bad financing reported by Islamic banks in the financial statements only as much as the quarter concerned (the amount of financing now quarter minus the amount of financing in the previous quarter period).

This research model uses an interaction test called the Moderated Regression Analysis (MRA). Equation formula is: 


$$
\begin{array}{ll}
Y=\alpha+\beta 3(X 1 M 1)+\varepsilon & i \\
Y=\alpha+\beta 8(X 2 M 1)+\varepsilon & \text { ii } \\
Y=\alpha+\beta 11(X 3 M 1)+\varepsilon & \text { iii } \\
Y=\alpha+\beta 14(X 4 M 1)+\varepsilon & \text { iv }
\end{array}
$$

\begin{tabular}{|c|c|}
\hline Y & NPF \\
\hline X1 & profit-based financing \\
\hline $\mathrm{X} 2$ & murabahah financing volume \\
\hline X3 & salam financing volume \\
\hline $\mathrm{X} 4$ & istishna financing volume \\
\hline M1 & Inflation \\
\hline$\beta \mathrm{i}$ & coefisien $(i=1,2,3,4, \ldots . . n)$ \\
\hline$\varepsilon$ & Error \\
\hline$\alpha$ & constanta \\
\hline
\end{tabular}

Description:

\section{Results and Discussion}

There are 10 samples of Islamic banks in this study. The sample in this study is Mandiri Syariah, Bukopin Syariah, Maybank, Victoria Syariah, BCA Syariah, BNI Syariah, BRI Syariah, Mega Syariah, Bank Muamalat, and Panin Syariah.

\section{Profit sharing has a significant effect on NPF with inflation as a moderating variable}

The Adjusted $\mathrm{R}^{2}$ is obtained at 0.435 . this means the effect of principle

\begin{tabular}{|c|c|c|c|c|}
\hline & Model & Standardized Coefficients & $\mathrm{t}$ & Sig. \\
\hline \multicolumn{5}{|c|}{ Beta } \\
\hline \multirow[t]{2}{*}{1} & (Constant) & 200,718 & 9,762 & 0,000 \\
\hline & AbsX1.X5 & 0,669 & 6,102 & 0,000 \\
\hline
\end{tabular}
financing of profit sharing on NPF with inflation as a moderating variable of $43.5 \%$. While the rest is explained by other factors outside the model.

Table 1. The Regression Analysis 
The results of the regression analysis of the effect of the principle of profit sharing on NPF with inflation as the moderating variable were obtained in table 1.

JIAFR | 90 From the table of regression analysis results can be concluded mathematical equations as:

$$
Y=200,718+0,669(X 1 \cdot M 1)+\varepsilon
$$

The constant of 200.718 states that if the independent variable is considered constant, then the NPF is 200.718. The regression coefficient of the financing relationship of the profit sharing principle on NPF is moderated by inflation of 0.669 , which means that for every addition of 1 , it will add to the NPF amount of 0.669 .

The main scheme in Islamic banks is to produce (mudharabah and musyarakah). In profit-based financing, there is a conflict of interest between each fund owner and business manager. Customers and banks want high profits. When this research was conducted an ongoing experiment. . Lowering income will be charged for repayment of debt and profit sharing. This encourages expenditures incurred from financial statements so as not to pay for large returns. Also repayment. This causes the NPF to affect the bank.

\section{Murabahah financing has a significant effect on NPF with inflation as a moderating variable}

The Adjusted $\mathrm{R}^{2}$ is 0.423 . this means the effect of murabahah financing on NPF with inflation as a moderating variable of $42.3 \%$. While the rest is explained by other factors outside the model.

The results of the regression analysis of the effect of murabahah financing on NPF with inflation as a moderating variable were obtained in table 2.

Table 2. The Regression Analysis

\begin{tabular}{lcccc}
\hline & Model & $\begin{array}{c}\text { Standardized Coefficients } \\
\text { Beta }\end{array}$ & t & Sig. \\
\hline \multirow{2}{*}{1} & (Constant) & 178,226 & 7,446 & 0,000 \\
\cline { 2 - 5 } & AbsX1.X5 & 0,660 & 5,954 & 0,000 \\
\hline
\end{tabular}


From the table of regression analysis results can be concluded mathematical equations as follows:

$$
Y=178.226+660\left(X_{2} M_{1}\right)+\varepsilon
$$

The constant of 178,226 states that if the independent variable is JIAFR | 91 considered constant, then the NPF is 178,226. Regression coefficient relationship of the effect of murabahah financing on NPF with inflation as a moderating variable of 0.660 , this means that every addition of 1 will increase the number of NPF by 0.660 .

In the murabahah scheme, the customer pays a certain margin that has been agreed at the beginning. The debt margin and principal must be paid according to the agreement. Murabahah is the main scheme in Islamic banks. The amount of murabahah funds is the biggest compared to other schemes. This happens in all Islamic banks. Chances are, customers choose to fulfill basic needs first and then pay off debts and margins. This possibility occurs in most customers so that NPF Islamic banks will be affected.

\section{Salam financing has a significant effect on NPF with inflation as a moderating variable}

The Adjusted $\mathrm{R}^{2}$ is 0.307 . this means the effect salam financing on NPF with inflation as a moderating variable of $30.7 \%$. While the rest is explained by other factors outside the model.

The results of the regression analysis of the effect of Salam financing on NPF with inflation as a moderating variable were obtained in table 3 .

Table 3. The Regression Analysis

\begin{tabular}{|c|c|c|c|c|}
\hline & Model & Standardized Coefficients & $\mathrm{t}$ & Sig. \\
\hline \multicolumn{5}{|c|}{ Beta } \\
\hline \multirow[t]{2}{*}{1} & (Constant) & 216,790 & 9,640 & 0,000 \\
\hline & AbsX1.X5 & 0,568 & 4,676 & 0,000 \\
\hline
\end{tabular}


From the table of regression analysis results can be concluded mathematical equations as follows:

$$
Y=216,790+0,568(X 3 \text { M1) }+\varepsilon
$$

JIAFR | 92 The constant of 216.790 states that if the independent variable is considered constant, then the NPF is 216.790 . Regression coefficient of Salam financing relationship to NPF with inflation as a moderating variable of 0.568 this means that each addition of 1 will increase the number of NPF of 0.568 .

A special characteristic in greeting contracts is repayment after the price agreement at the time of the agreement. When this research was conducted, high inflation was occurring, which affected the ability of customers to pay the agreement price. Because the possibility of the price offered by the bank is too high, but the customer really needs the financing for his business. So that this has an effect on the smooth repayment of greetings transactions

\section{Istishna financing has a significant effect on NPF with inflation as a moderating variable}

The Adjusted $\mathrm{R}^{2}$ value is 0,250 . this means istishna financing of NPF with inflation as a moderating variable of $25 \%$. While the rest is explained by other factors outside the model.

The results of the regression analysis of the effect of istishna financing on NPF with inflation as a moderating variable were obtained in table 4 .

Table 4. The Regression Analysis

\begin{tabular}{|c|c|c|c|c|}
\hline & Model & Standardized Coefficients & $\mathrm{t}$ & Sig. \\
\hline \multicolumn{5}{|c|}{ Beta } \\
\hline \multirow[t]{2}{*}{1} & (Constant) & 236,098 & 11,102 & 0,000 \\
\hline & AbsX1.X5 & 0,516 & 4,068 & 0,000 \\
\hline
\end{tabular}

From the table of regression analysis results can be concluded mathematical equations as follows:

$$
Y=236,098+0,516(X 4 M 1)+\varepsilon
$$


The effect of non performing financing volume with inflation ...

The constant of 236,098 states that if the independent variable is considered constant, then the NPF is 236,098. The regression coefficient of istishna financing relationship to NPF with inflation as a moderating variable of 0.516 means that every addition of 1 will increase the NPF amount by 0.516 .

JIAFR | 93

Istishna is usually used to finance physical or infrastructure development projects. The high inflation causes an increase in the price of goods, an increase in a number of costs and causes a decrease in customer income, thereby reducing the ability of customers to pay debts. Maybe the bank is not careful in estimating the inflation that occurs so that this causes the NPF of Islamic banks to increase.

Financing with the principle of profit sharing is actually a distinctive feature in Islamic banking. Profit sharing in sharia banking, mudharabah and musyarakah. In this study, the test results of the analysis of the effect of all financing on NPF with inflation as a moderating variable obtained results of significance of less than 0.5 , meaning the amount of financing, both the principle of profit sharing and buying and selling, moderated by inflation factors was able to influence the NPF amount. According to the agency theory, the principal has delegated the authority to manage the business to the agent but then conflicts of interest occur. In the case of channeling funds from Islamic banks to customers, the agent is a customer of Islamic banks and the principal is the management of Islamic banks. The management asks the recipient of funds to always be on time to settle debts and profit sharing. But the customer also has an interest in raising his business and/or earning more profit from the business that has been carried out. This may cause customers to lie when paying off their debts to Islamic banks so that NPF Islamic banks become high. The greater the amount of financing channeled to troubled customers it will affect the high NPF. Similar to the Mutamimah and Chasanah (2002) research, the amount of funding allocation has an effect on NPF. Likewise the results of research conducted by Legowati and Prasetyo (2016), the volume of financing has an effect on NPF. 
Apart from the bank's internal factors in the form of the large amount of funding channeled, external factors that also influence inflation. According to the research of Barus and Erick (2016), Amin, et al (2017) and Saekhu (2015), inflation has an effect on NPF. Indonesia's economic conditions in the past 2 (two) years have experienced high inflation. This certainly affects the financial condition of the business of sharia bank customers and influences the ability of customers to pay debts to Islamic banks.

This needs to be a concern for Bank Indonesia to participate in monitoring the country's monetary situation so that inflation is not high. If inflation is high, it is likely that the community will choose to fulfill their needs, after which they pay their debt.

\section{Conclusion}

Profit sharing an effect on NPF with inflation as a moderating variable. More funding is given to customers and is influenced by high inflation, causing NPF to increase. Because there may be a tendency to decrease customer income, so customers have difficulty paying off debts. Murabahah financing an effect on NPF with inflation as a moderating variable. The more murabahah financing given to customers and influenced by inflation, will cause NPF to increase. Because the possibility of the customer will choose to fulfill basic needs first and then pay off the debt. Salam financing has an effect on NPF with inflation as a moderating variable. High inflation is likely to affect the income of customers, which affects the ability to pay debts. Istishna financing has an effect on NPF with inflation as a moderating variable. Istishna is usually used to finance physical or infrastructure development projects. The high inflation causes an increase in the price of goods which causes a decrease in customer income, thereby reducing the ability of customers to pay debts. 
The effect of non performing financing volume with inflation ...

\section{References}

Amin, R. (2017). Faktor-faktor yang Mempengaruhi Non-Performing Financing: Studi Kasus Pada Bank dan BPR Syariah di Indonesia. Jurnal Masharif Al-Syariah:Jurnal Ekonomi dan Perbankan Syariah, 2(2).

Borus, A. C., \& Erick. (2016). Analisis Faktor-faktor yang Mempengaruhi JIAFR | 95 NonPerforming Loan Pada Bank Umum Di Indonesia. Jurnal Wira Ekonomi Mikroskil. 6(2).

Ghozali, I. (2006). Aplikasi Analisis Multivariate dengan Pro ram SPSS, Semarang: Badan Penerbit Universitas Diponegoro.

Jumono, S. (2012). Bank Sehat. Universitas Esa Unggul.

Karim, A. A. (2004). Bank Islam: Analisis Fiqh dan Keuangan. Rajawali Pers: Jakarta.

Kasmir. (2007). Manajemen Perbankan. PT Raja Grafindo Persada: Jakarta.

Legowati, D. A., \& Ari, P. (2016). Pengaruh Pembiayaan Berdasarkan Jenis Pengguanaan Terhadap Non Performing Financing pada Bank Umum Syariah (BUS) dan Unit Usaha Syariah (UUS) di Indonesia Periode Januari 2009 - Desember 2015. Jurnal Ekonomi Syariah dan Teori Terapan, 3(12).

Maidalena. (2014). Analisis Faktor Non Performing Financing (NPF) pada Industri Perbankan Syariah. Human Falah. 1(1).

Mutamimah \& Siti, N. Z. Chasanah. (2012). Analisis Eksternal dan Internal Dalam Menentukan Non Performing Financing Bank Umum Syariah Di Indonesia. Jurnal Bisnis dan Ekonomi, 19(1).

Saekhu. (2015). Pengaruh Inflasi terhadap Kinerja Pembiayaan Bank Syariah, Volume Pasar Uang antara Bank Syariah dan Posisi Outstanding Sertifikat Wadiah Bank Indonesia. Jurnal Economica. 6(1).

Sofyani, H., Ihyaul, U., Daniel, S., \& Sri W. L. (2012). Islamic Social Reporting Index Sebagai Model Pengukuran Kinerja Sosial Perbankan Syariah (Studi Komparasi Indonesia Dan Malaysia). Jurnal Dinamika Akuntansi. 4(1), 36-46.

Soumadi, M. M., \& Bassam, F. A. (2011). Growth Strategy and Bank Profitability: Case of Housing Bank for Trade and Finance. European Scientific Journal, 8(22). 
Mirasanti Wahyuni, Fika Azmi

Sumarti. (2007). Analisis Kinerja Keuangan Pada Bank Syariah Mandiri di Jakarta. Skripsi. Universitas Muhammadiyah Surakarta: Surakarta.

Syahyunan. (2002). Analisis Kualitas Aktiva Produktif Sebagai Salah Satu Alat Ukur Kesehatan Bank. USU Digital Library.

JIAFR | 96 Setiawan, A. B. (2009). Kesehatan Finansial dan Kinerja Sosial Bank Umum Syariah di Indonesia. Materi Seminar Ilmiah Kerjasama Magister Bisnis Keuangan Islam Univ. Paramadina. Ikatan Ahli Ekonomi Islam (IAEI) Pusat dan Masyarakat Ekonomi Syariah (MES).

Triyuwono, I. (2003). Konsekuensi Penggunakan Entity Theory Sebagai Konsep Dasar Standar Akuntansi Perbankan Syari'ah.JAAI, 7(1).

Undang-Undang Republik Indonesia Nomor 21 Tahun 2008 tentang Perbankan Syariah. 